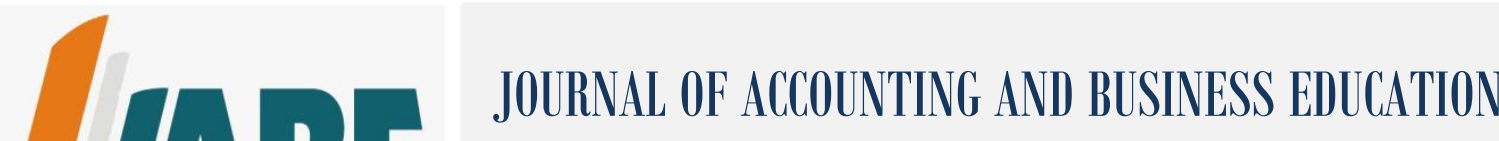 \\ P-ISSN 2520-7201 E-ISSN 2528-729X \\ E-mail: jabe.journal@um.ac.id \\ http://journal2.um.ac.id/index.php/jabe/
}

\section{Premature Sign-Off of Audit Procedure}

\author{
Maryam Hafidhatul Izzah ${ }^{1}$ \\ Nujmatul Laily ${ }^{2}$ \\ ${ }^{1,2}$ Accounting Department, Faculty of Economic, Universitas Negeri Malang, Indonesia \\ email: mhafidhatulizzah@gmail.com
}

DOI: http://dx.doi.org/10.26675/jabe.v4i2.8173

\begin{abstract}
This research aims at testing influence of time pressure on premature sign-off of audit procedure with professional commitment as the moderating variable. This research uses questionnaire to collect the data. Meanwhile, the population in this research are all independent auditors working for Public Accountant Offices in Malang, Indonesia. Amounting to a total of 50 auditors are used as the sample in this research. The sample in this this research is taken using purposive sampling. The result indicates that time pressure has a positive influence on premature signoff of audit procedure. This means the greater the time pressure the auditors are having, the more likely the auditors to be involved in premature sign-off of audit procedure practice, and vice versa. The second finding is that professional commitment weakens the influence of time pressure on premature sign-off of audit procedure. This means if an auditor is faced with high time pressure yet he/she possesses high professional commitment then the possibility of this auditor to get involved in premature sign-off of audit procedure practice is lower, and vice versa.
\end{abstract}

Keywords: Time Pressure, Professional Commitment, Premature sign-off of audit procedure

\section{INTRODUCTION}

Companies need to perform audit to their financial statements in order to improve the quality of its financial statements made by its accountants. This audit is performed by external auditors who in their audit process refers to the applicable standards, i.e. International Standards on Auditing (ISA). However, in practice many auditors perform their audits not in compliance with ISA, and the practice of audit quality reduction or commonly known as Reduced Audit Quality (Coram et al, 2003) is one example of their noncompliance. Included in this Reduced Audit Quality that some auditors might do is the premature signoff of audit procedure practice (Coram et al, 2003). This practice has something to do with ignorance or even termination of the procedures supposedly to be done in an audit program; auditors fail to follow the procedures thoroughly, yet they pass an audit opinion before accomplishing their job thoroughly (Wahyudi et al, 2011).

The SNP Finance case is one of cases related to premature sign-off of audit procedure practice. On July 2017, SNP Finance was found fabricating financial statements and caused losses to 14 banks in Indonesia up to trillions rupiah. This SNP Finance's fraud case also dragged the Public Accountant Office Satrio Bing Eny (SBE) which was affiliated to Deloitte and during that time audited PT Sunprima Nusantara Pembiayaan's (SNP Finance) financial statements. Upon further investigation, KAP SBE was deemed to have not completely fulfill the audit standards and professional standards of public accountant in performing a general audit on SNP Finance's financial statements. For example, information system control related to customer data and accounts receivable financing journal accuracy, and obtained no 
adequate and accurate audit evidence of the customer's accounts receivable financing. Also, the quality control system owned by KAP had a weakness in terms of its inability to prevent familiarity threat in the form of fairly long-standing relationship between senior personnel in audit engagement in the clients. This led to the decreasing professional scepticism the auditor ought to have at all times. This KAP was found having audited the company since 2012 to 2016 fiscal years. On that basis, the state treasurer passed administrative sanction to the KAP by restraining the involved public accountants from providing audit services to any financial service entity for 12 months, effective as of 16 September 2018 to 15 September 2019.

Another case related to premature sign-off of audit procedure is the case of KAP Meilina Pangaribuan which audited PT Jui Shin Indonesia's 2015 financial statements. KAP Meilina Pangaribuan did not perform an audit according to the procedure, i.e. it did not collect audit evidences of sales account, cost of goods sold, and tax debt. This was deemed as gross violation since it significantly influenced the financial statements, and eventually KAP Meilina Pangaribuan was sanctioned, i.e. license suspension for a year. Based on the cases above, we can see that many auditors still commit premature sign-off of audit procedure practice.

According to th research conducted by Andani \& Mertha (2014), the reasons behind an auditor's decision to commit premature sign-off of audit procedure include time pressure, audit risk, locus of control and professional commitment. Meanwhile, according to the study conducted by Karim et al. (2015) when an auditor commits premature sign-off of audit procedure, it is due to time pressure, materiality, and lack of monitoring from the auditor manager. From these studies, it can be seen that internal and external factors are the cause for an auditor to commit premature sign-off of audit procedure practice. This is consistent with Weningtyas et al (2006) who suggest that premature sign-off of audit procedure is due to the auditor's personal characteristic factor, in which this characteristic constitutes an internal factor and situational factor when performing the audit (external factor). These statements are directly proportional with Fritz Heider's (1958) attribution theory which explains that an individual's behavior is influenced by both internal and external factors.

One of the external factors indicated to influence premature sign-off of audit procedure is time pressure. Time pressure is a condition in which an auditor receives pressure from the Public Accountant Office he/she is working for to complete the audit at a predetermined time and costs (Wahyudi et al, 2011). Time pressue can lead an auditor to behave positively (asking more questions and getting motivated to complete the job) or negatively (by getting involved in audit quality reduction practice) (Cook and Kelly, 1991 in Gundry \& Liyanarachchi, 2007). Majid \& Asse's (2018) found that time pressure has a positive influence on auditor's dysfunctional behavior. It is allegedly because the auditor thinks that in performing the audit he/she has to follow the time budget which has been set. Time budget is also deemed to have some association with auditor's performance assessmen and this will eventually make the auditor force themselves to complete the audit according to the time budget, even if he/she has to commit dysfunctional behaviors.

In some studies, it is found that time pressure gives a positive influence on dysfunctional audit behaviour or premature sign-off of audit procedure (Coram et al, 2003; Karim et al, 2015; Weningtyas et al, 2006; Gundry \& Liyanarachchi, 2007, Siregar et al, 2018, Istiqomah \& Hanny, 2017). When an auditor needs to complete the audit task within a brief period of time, they are more likely to ignore or disregard some audit procedure they think immaterial and less important. In addition, they merely accept the client's explanation without checking and reviewing extensively the client's document (Karim et al, 2015). This means when an auditor is faced with high time pressure, it is more likely for the auditor to commit premature sign-off of audit procedure practice.

Meanwhile, Wahyudi et al (2011) and Anita et al (2014) found that time pressure has no influence on premature sign-off of audit procedure practice. This is because the auditor think he/she has to continue to work professionally (in this case, performing all steps in audit procedure) despite having to deal with time pressure while auditing their clients. Previous studies show different findings, leading to ambiguity in drawing conclusion. For this reason, the research re-tests the influence of time pressure on premature signoff of audit procedure. 
The time pressure variable in the research conducted by Alderman \& Deitrick (1982) in Weningtyas (2006) constitutes the main factor many auditors choose as the reason behind their decision to commit dysfunctional behavior such as premature sign-off of audit procedure practice. This result finding is also supported by Coram et al, (2003) who also find that the most common (main) reason chosen by auditors behind their decision to commit dysfunctional behavior is time pressure. These studies show that time pressure is an external factor with highly strong influence on auditor to commit dysfunctional behavior, including premature sign-off of audit procedure practice.

After being faced with the external factor most commonly chosen by auditors as the reason behind their premature sign-off of audit procedure practice, there is also an internal factor with equally strong influence on an auditor to commit premature sign-off of audit procedure, namely professional commitment. Professional commitment is defined as an individual's relative power to be identified and engaged to a profession (Hartanto, 2016). According to Shaub et al., (1993) in Silaban (2010) professional commitment is an important factor which influences an auditor's behavior in dealing with ethical issues. Meanwhile according to Aranya et al., (1981) a person's commitment to his/her profession is materialized in three characteristics below; (1) an acceptance of professional goals and values, (2) a willingness to exercise the best attempts for the purpose of the profession, and (3) a desire to maintain and keep their membership in the profession. This means auditors with high professional commitment will not be involved in dysfunctional practices which may harm themselves and their profession since they possess characteristics, i.e. willing to accept professional goals and values, trying their best for their profession, and maintaining and keeping their membership in the profession.

Previous studies found that professional commitment (as an independent variable) has a negative influence on auditor's dysfunctional behavior (Alkautsar, 2014; Hartanto, 2016, Tamara, 2017). Meanwhile, Andani et al (2014) and Fakhar \& Hoseinzadeh (2016) find that professional commitment has a significant negative influence on premature sign-off of audit procedure practice (one example of auditor's dysfunctional behavior) and other dysfunctional behaviors. This means the greater the professional commitment owned by an auditor within themselves, the less likely for this auditor to commit dysfunctional behavior (including premature sign-off of audit procedure practice).

Kesuma \& Dwindra's (2019) found that time pressure has a negative influence on audit quality, and the second finding is that professional commitment can weaken the influence of time pressure on audit quality. This means the higher the time pressure level encountered by an auditor, the more likely the quality of audit to be produced to be weaker. However, when this auditor has high professional commitment in themselves, then even high time pressure will not have any influence on the quality of audit he/she produces. This proves that an auditor with high professional commitment is less likely to commit deviant behaviors which may compromise the quality of audit they generate even if they are under a high time pressure.

As to what makes this research different from those studies previously conducted is its variables. This research tests an external factor which has a strong influence on premature sign-off of audit procedure practice, namely time pressure, which is then assigned as an independent variable and an internal factor which has a strong influence to refrain an auditor from comitting premature sign-off of audit procedure practice which is then used as a moderating variable. This is done in order to find new knowledge of whether or not a moderating variable can influence the existence of independent variable on dependent variable. 


\section{LITERATURE REVIEW AND HYPOTHESES}

\section{Attribution Theory}

This attribution theory was developed by Heider (1958) who argued that a person's behavior was determined by a combination of internal forces, i.e. factors from within that very person, such as ability or effort, and external forces, i.e. factors from the outside, such as difficulties in job or luck (Ikhsan and Ishak, 2008). Meanwhile, according to Lestari (2010) internal causes tend to refer to individual's behavioral aspects, something which has been within a person such as personal characters, self perception, ability, and motivation. Meanwhile, external causes refer more to the environment which influences a person's behavior, such as social conditions, social values, and community's view.

The association between Heider's attribution theory and this research is that both observe the (internal/external) factors in a phenomenon. In this research, the researchers test two external factors (time pressure) allegedly causing auditor to commit premature sign-off of audit procedure and one internal factor suspected or expected to prevent auditors from committing premature sign-off of audit procedure, i.e. professional commitment. Upon knowing the factors triggering premature sign-off of audit procedure practice, it is expected that these factors could later be minimized and, therefore, the probability of an auditor to commit this practice can be reduced.

\section{Time Pressure and Premature Sign-Off of Audit Procedure}

Time pressure is a condition in which an auditor receives a pressure from the client or the Public Accountant Office he/she is working for to complete the audit at a predetermined time and cost budget (Wahyudi et al, 2011). Completing an audit procedure in the presence of time pressure will of course lead to different result when the audit procedure is completed under no time pressure (Weningtyas et al., 2006). Time pressure has generally been proven to have a detrimental impact on individual's decision making process. For example, in Edland and Svenson's (1987) research in Gundry \& Liyanarachchi (2007), it is found that individual's performance accuracy is more likely to decrease when they are face with time pressure. In general, stress and performance tend to have inverse relationship, and time pressure can be the main source of stress (Maule and Svenson, 1993 in Gundry \& Liyanarachchi, 2007).

Majid \& Asse's (2018) found that time pressure has a positive influence on auditor's dysfunctional behavior . It is suspected that this is because the auditor thinks that in performing the audit they have to follow the predetermined time budget. Time budget is also deemed to have something to do with auditor's performance assessment; this will eventually make the auditor to push themselves to perform the audit according to the time budget even if they have to commit dysfunctional behaviors. Additionally, when an auditor needs to complete their audit job within a brief period of time, they might tend to ignore or disregard several steps of audit procedure they think immaterial and unimportant (Karim et al., 2015).

Relating this to Heider's (1958) attribution theory who stated that a person's behavior was determined by external and internal factors, then in this case, time pressure is an external factor which makes an auditor stressed and lowers his/her performance and eventually it serves as the basis for an auditor to commit dysfunctional behavior, i.e.. premature sign-off of audit procedure. This means the higher the time pressure faced by an auditor, the more likely for him/her to commit premature sign-off of audit procedure practice (Coram et al., 2003; Gundry \& Liyanarachchi, 2007; Karim et al., 2015; Rochman et al., 2016; Weningtyas et al., 2006, Siregar et al, 2018, Istiqomah \& Hanny, 2017). As explained above, for an auditor time pressure has a strong influence on premature sign-off of audit procedure practice, thus the hypothesis to be tested is as follows:

$\mathrm{H}_{1}$ : Time pressure has an influence on premature sign-off of audit procedure.

\section{Professional Commitment Moderates Time Pressure on Premature Sign-Off of Audit Procedure}

Professional commitment is an individual's characteristics which have an influence on his/her belief in controlling the situation or condition he/she faces, thus an auditor's commitment to his/her profession may have an influence on his/her behavior in doing the audit program. Professional commitment is defined as an individual's relative power to be identified and engaged to a profession (Hartanto, 2016). Associating 
it with attribution theory, a person tends to do something due to an external or internal factor. In this case, the auditor refraining himself/herself from committing premature sign-off of audit procedure is due to internal factor, i.e. professional commitment within the auditor. In this research, professional commitment becomes an example of internal factor which prevent a bad factor (such as time pressure) from entering the auditor's mind and eventually from committing dysfunctional practices.

Professional commitment prevents the auditor from commiting those practice which contradict their profession (premature sign-off of audit procedure practice). Meanwhile, some studies support the idea that professional commitment can prevent individuals from comitting premature sign-off of audit procedure practice (dysfunctional behavior) (Alkautsar, 2014; Hartanto, 2016; Andani et al, 2014; Fakhara \& Hoseinzadeh, 2016, Tamara, 2017). Kesuma \& Dwindra (2019) found that time pressure has a negative influence on audit quality, and the second finding is that professional commitment can weaken the influence of time pressure on audit quality. This means the higher the time pressure an auditor has to deal with, the weaker the quality of audit he/she produces would be. However, when this auditor has a high professional commitment within himself/herself, then the high time pressure will not have an influence on the quality of audit he/she generates. This also proves that an auditor with high professional commitment level is more likely to refrain himself/herself from committing deviant behaviors which might compromise the quality of audit he/she produces even when he/she is under a high time pressure.

As explained earlier, the external factor most auditors choose as the main factor which causes them to commit premature sign-off of audit procedure practice is time pressure (Coram et al., 2003; Gundry \& Liyanarachchi, 2007; Karim et al., 2015; Rochman et al., 2016; Weningtyas et al., 2006). Therefore, this research aims to test how professional commitment as the internal factor considered capable of making auditors refrain themselves from committing dysfunctional behavior, i.e.. committing premature sign-off of audit procedure practice, can moderate the influence of time pressure on premature sign-off of audit procedure. Based on the explanation above, the hypothesis to be tested is as follows:

$\mathrm{H}_{2}$ : Professional commitment moderates the influence of time pressure on premature sign-off of audit procedure.

\section{METHODS}

The approach used in this research is the correlational one. Correlational approach is the approach which sees the correlation between one variable to another. This is research with quantitative method. The sample used in this research is auditors of Public Accountant Office in Malang Municipality which makes a total of 50 auditors and the sampling method uses purposive sampling. The criteria of the sample used are that the respondents must be an auditor who works for a Public Accountant Office in Malang, Indonesia. The respondents are limited to the positions of supervisior/manager, senior auditor, and junior auditor. The respondents who assume the position as a partner are excluded from the sample in this research since they do not perform the audit assignment directly.

The primary data are collected using questionnaire which is distributed to Public Accountants working for Public Accountant Offices in Malang Municipality. Premature sign-off audit procedure is a practice that occurs when the auditor ignoring some required audit procedures but he can provide an opinion on a financial statement (Shapeero et al., 2003). Time pressure is a condition where the auditor gets pressure from the client or the Public Accounting Firm where he works, to complete the audit at a predetermined time and will negatively impact the auditor's performance. The instrument used for premature sign-off of audit procedure and time pressure are taken from Weningtyas et al (2006). Professional commitment is an individual characteristic that influences a person's beliefs in controlling his behavior. This instrument adopted from Smith \& Hall (2008). 


\section{RESULTS}

\section{Respondent Characteristics}

Based on the website of Ikatan Akuntan Publik Indonesia (IAPI), there are 13 Public Accountant Offices in Malang Municipality. Yet, in this research only 7 (seven) of them are willing to complete the research questionnaire. The total number of research questionnaires distributed to respondents is 58 questionnaires, and the returned and processable ones is only 50 questionnaires or $86 \%$ of the total respondents. Some auditors in some Public Accountant Offices fail to complete the questionnaire since they are too busy auditing while the research is being conducted. The characteristics of respondents by sex are $42 \%$ of them are male and $58 \%$ of them are female. By education, $82 \%$ of the auditors completed their S1 degree, and the remining 18\% of them completed their D3 degree. By position, $74 \%$ of the auditors are junior auditors, $14 \%$ are senior auditors, and $12 \%$ are supervisiors. Based on their time of service as an auditor, $88 \%$ of the auditors have work experience in auditing for 1-5 years, $7 \%$ of them $6-10$ years, and $5 \%$ of them $11-15$ years.

\section{Interaction Test}

The interaction test in this research used Moderated Regression Analysis. Moderated Regression Analysis employs analyitical approach which maintains the sample integrity and provides the basis for controlling the influence of moderating variable (Ghozali, 2018:227). A moderating variable is an independent variable which will strengthen or weaken the correlation between another independent variable on the dependent variable. The moderated regression analysis in this research is used to test whether the professional commitment variable is the one which moderates the influence of time pressure on premature sign-off of audit procedure.

Table 1. Result of Moderated Regression Analysis (MRA)

\begin{tabular}{lccc}
\hline Variable & $\begin{array}{c}\text { Unstandardized } \\
\text { coefficient }\end{array}$ & $\begin{array}{c}\text { Standardized } \\
\text { coefficient }\end{array}$ & Sig \\
\hline & B & Beta & 0,000 \\
Time pressure & 2.745 & 1.744 & 0,057 \\
Professional commitment & 0,915 & 0,590 & 0,004 \\
TP*PC & $-0,125$ & -1.037 & \\
\hline
\end{tabular}

From the result of SPSS output test above, the significance value of time pressure $<0.05$. This means time pressure has an influence on premature sign-off of audit procedure, with positive unstandardized coefficients result. Based on this fact, then $\mathrm{H}_{1}$ is confirmed. The interaction test generates a sig value $<0.05$. This means the professional commitment variable is a pure moderating one, meaning that this variable can only be used as a moderating variable and cannot be used as an independent variable. Based on the result of unstandardized coefficients, the data shows a negative direction, meaning that the professional commitment variable has a moderating nature which weakens the influence of time pressure on premature sign-off of audit procedure. Based on this fact, then $\mathrm{H}_{2}$ is confirmed.

\section{DISCUSSION}

\section{Time pressure has an influence on premature sign-off of audit procedure}

Hypothesis 1 states that time pressure has an influence on premature sign-off of audit procedure. Based on the result, it is found that the time pressure occuring at Public Accountant Office in Malang Municipality has an influence on the incidence of premature sign-off of audit procedure practice. This indicates that the higher the time pressure faced by an auditor in auditing their client's financial statements the more likely for premature sign-off of audit procedure practice to occur. The opposite is also true, the lower the time pressure faced by an auditor the less likely for this auditor to commit premature sign-off of audit procedure. Thus, hypothesis 1 proposed in this research can be accepted. 
This result is consistent with Heider's (1958) attribution theory which explains that a person's behavior does not abruptly occur, rather some factors are behind a person's behavior. Meanwhile, the factors behind a person's behavior consist of internal and external factors. In this research, time pressure becomes an example of external factor which leads an auditor to commit premature sign-off of audit procedure practice. This is because when an auditor needs to complete their audit job within a brief time, they are more likely to ignore and disregard some steps in audit procedure they think immaterial and unimportant (Karim et al, 2015). From this explanation, it can be concluded that one of external factors which influence an auditor to commit premature sign-off of audit procedure is time pressure.

Based on the data analysis result, the respondents in this research are mostly women at $58 \%$ who mostly assume the position of junior auditor at $74 \%$ and senior auditor at $14 \%$. Most auditors in this research have worked as an auditor for 1-5 years at $88 \%$. The percentage of respondent's answers to questions on time pressure variable is dominated by frequent category at $38 \%$. It means this result explains that an auditor is frequently faced with time pressure when performing their job.

In terms of the situation when the assignment is in progress, most junior auditors in Malang Municipality experience frequent time pressure at $63 \%$ or 12 junior auditors. Meanwhile, the time pressure experienced by senior auditors and supervisiors in Malang Municipality is relatively low at $21 \%$ or 4 senior auditors and $16 \%$ or 3 supervisiors respectively. Based on this analysis result, it can be seen that in this research junior auditors experienced time pressure more frequently than the senior auditors and supervisors.

This result is consistent with the research conducted by Coram et al (2003), Karim et al (2015), Weningtyas et al (2006), and Gundry \& Liyanarachchi (2007) who all find that time pressure has positive influence on audit's dysfunctional behaviors or premature sign-off of audit procedure. The higher the time pressure experienced by an auditor, the more likely this auditor to commit premature sign-off of audit procedure practice (and vice versa). Karim et al's (2015) found that the procedure most frequently termined is vouching of expenses. In this research, it is found that the step of audit procedure most frequently terminated is reducing the number of sample which has been planned in auditing financial statements, and this is also consistent with Weningtyas et al's (2006) research who find that the auditors acknowledge that the premature sign-off of audit procedure practice they usually commit is reducing the number of sample in an audit, performing shallow review on client's documents, and not expanding the examination when a questionable item is found.

From the explanations above, it can be concluded that $\mathrm{H}_{1}$ which states time pressure has an influence on premature sign-off of audit procedure is accepted. Meanwhile, the influence of time pressure on premature sign-off of audit procedure is positive, meaning that the higher the time pressure experienced by an auditor, the more likely for this auditor to commit premature sign-off of audit procedure (and vice versa). This is because when an auditor is faced with time pressure, then this auditor is more likely to skip the audit procedures they think not too important and this will lead to premature sign-off of audit procedure practice.

\section{Professional commitment moderates the influence of time pressure on premature sign-off of audit procedure}

The second hypothesis in this research states that professional commitment moderates the influence of time pressure on premature sign-off of audit procedure. Based on the result, it is found that professional commitment moderates the influence of time pressure on premature sign-off of audit procedure. This means the higher the professional commitment possessed by an auditor, the weaker the influence of time pressure on premature sign-off of audit procedure. The opposite is applies, i.e. the lower the professional commitment owned by an auditor, the more likely for this auditor to commit premature sign-off of audit procedure. Thus, hypothesis 2 proposed in this research is confirmed.

Based on the result of Moderated Regression Analysis (MRA), it is found that professional commitment variable is a pure moderation variable and not a quasi moderation variable. This means that the professional commitment variable in this research can only be used as a moderating variable, rather than an independent one. 
The result of descriptive analysis shows that the percentage of respondent answers to questions on professional commitment variable are dominated by high category at 50\%. This means this result explains that the auditors who works for Public Accountant Offices in Malang Municipality have high professional commitment. Meanwhile, the agree choice in the research questionnaire is mostly selected by junior auditors at $81 \%$ or 21 junior auditors. Meanwhile, for senior auditors and supervisiors in Malang Municipality, it is relatively low, amounting to the same number at $8 \%$ respectively or only 2 senior auditors and 2 supervisiors. Based on this result, it could be concluded that junior auditors have higher professional commitment.

This research result is consistent with Heider's (1958) attribution theory which explains that a person's behavior does not abruptly occur, rather some factors are behind a person's behavior. Meanwhile, the factors behind a person's behavior consist of internal and external factors. In this research, professional commitment becomes an example of internal factor which prevents bad factors from playing some role within the auditors' mind and eventually prevents the auditor from committing dysfunctional practices. This is confirmed by Aranya et al, (1981) who suggest that an auditor with high professional commitment will not get involved in dysfunctional practices (including premature sign-off of audit procedure practice) which may harm himself/herself and his/her profession for they possess certain characteristics, including willingness to accept professional goals and values, exercising the best attempts for the purpose of their profession, and maintaining and keeping their membership in their profession. Based on the explanations in the previous chapter, the professional commitment of auditors in Malang Municipality is relatively high, meaning that the professional commitment variable can indeed minimize/weaken the influence of time pressure on premature sign-off of audit procedure which occurs in Public Accountant Offices in Malang Municipality.

This result is consistent with the research conducted by Alkautsar (2014) and Hartanto (2016) who find that professional commitment has a negative influence on dysfunctional audit behavior, meaning that if within an auditor himself/herself there is a high professional commitment, then the possibility for an auditor to commit dysfunctional behaviors will be decreasing (and vice versa). This research result is also in line with the studies conducted by Andani et al (2014) and Fakhar \& Hoseinzadeh (2016) who suggest that an auditor with high professional commitment is less likely to commit premature sign-off of audit procedure practice.

\section{CONCLUSION}

Based on the result of research which has been conducted, it is found that time pressure has a positive influence on premature sign-off of audit procedure. Another finding of this research is that professional commitment weakens the influence of time pressure on premature sign-off of audit procedure. Based on these explainations, it can be said that this research has successfully proved empirically the applicability of Heider's attribution theory who suggests that whether an auditor commits or refrains from committing premature sign-off of audit procedure practice is due to an external factor in the form of time pressure and internal factor in the form of professional commitment. This research has a limitation, i.e. its questionnaire is distributed not at the right time for when it is distributed some auditors are too busy auduting their clients, leading to the low response rate and some KAPs even do not return the questionnaire since their auditors are too busy and the researcher does not personally wait for the questionnaire to be completed, thus whether the research questionnaire is actually completed by the research respondents or by others remains unknown. Meanwhile, the suggestions the researcher could offer for further studies is to investigate other variables possibly capable of influencing an auditor in committing dysfunctional actions for finding a way to solve and minimize them. 


\section{REFERENCES}

Alkautsar, M. (2014). Locus of control, commitment profesional and dysfunctional audit behaviour. International Journal of Humanities and Management Sciences (IJHMS), 2(1), 35-38.

Andani, N. M. S., \& Mertha, I. M. (2014). Pengaruh time pressure, audit risk, professional commitment dan locus of control pada penghentian prematur atas prosedur audit. E-Jurnal Akuntansi Universitas Udayana, 6(2), 185-196.

Anita, Y. T., Yusralaini, \& Kurnia, P. (2014). Pengaruh time pressure, resiko audit, locus of control, dan turnover intentions terhadap penghentian prematur atas prosedur audit (studi empiris pada kantor akuntan publik di Pekanbaru, Padang, Jambi dan Batam). Jurnal Akuntansi, 1(2), 1-15.

Aranya, N., Polibck, J., \& Amernic, J. (1981). An examination of professional commitment in public accounting. Accounting, Organizations and Society, 6(4), 271-280.

Asmara, C. G. Kasus SNP Finance, Sri Mulyani Hukum Deloitte Indonesia. https://www.cnbcindonesia.com/market/20180830074647-17-30904/kasus-snp-finance-sri-mulyanihukum-deloitte-indonesia, diakses 2 oktober 2018.

Coram, P., Ng, J., \& Woodliff, D. (2003). A survey of time budget pressure and reduced audity quality among Australian auditors. Australian Accounting Review, 13(1), 38-44.

Fakhar, P. T., \& Hoseinzadeh, A. (2016). Investigate the effect of organizational commitment and professional commitment on dysfunctional behavior of auditors. International Academic Journal of Accounting and Financial Management, 3(1), 1-12. https://doi.org/10.1016/j.ultramic.2010.01.002

Ghozali, Imam. 20018. Aplikasi Analisis Multivariate Dengan Program SPSS. Cetakan Kesembilan. Semarang: Badan Penerbit Universitas Diponegoro.

Gundry, L. C., \& Liyanarachchi, G. A. (2007). Time budget pressure, auditors' personality type, and the incidence of reduced audit quality practices. Pacific Accounting Review, 19(2), 125-152. https://doi.org/10.1108/01140580710819898

Halil Paino. (2012). Organizational and professional commitment on dysfunctional audit behaviour. African Journal of Business Management, 6(4), 1434-1440. https://doi.org/10.5897/ajbm11.1974

Hartanto, O. (2017). Pengaruh locus of control, tekanan anggaran waktu, komitmen profesional, terhadap perilaku disfungsional auditor. Jurnal Ekonomi Dan Keuangan, 20(4), 473. https://doi.org/10.24034/j25485024.y2016.v20.i4.1826

Istiqomah, S. F., \& Hanny, R. Y. (2017). Studi Empiris Faktor-Faktor yang Memengaruhi Perilaku Disfungsional Auditor. Jurnal Akuntansi/Volume XXI, No. 02, 184-207.

Karim, M. S., Paino, H., Jabar, F. A., Pauzi, N. F. M., \& Bakar, S. A. N. A. (2015). Factors contributing to premature sign-off of audit procedure: Evidence from Malaysia. Advanced Science Letters, 21(5), 1243-1246. https://doi.org/10.1166/asl.2015.5991

Kesuma, I. B. G. P. W., \& Dwirandra A. A. N. B. (2019). Professional Commitments and Pressure of Obedience in Mediating on The Effect of Time Budget Pressure in Quality Audits. International Research Journal of Engineering, IT \& Scientific Research, 27-38. https://doi.org/10.21744/irjeis.v5n1.587

Majid, J., \& Asse, A. (2018). Time Budget Pressure and Turnover Intention with Dysfunctional Accountant Behaviour. International Journal Economics Management and Social Science, 9-16. https://doi.org/10.32484/ijemss.v1i1.3 
Nurmayanti. Begini Awal Mula Kasus SNP Finance yang Rugikan 14 Bank. https://www.liputan6.com/bisnis/read/3653257/begini-awal-mula-kasus-snp-finance-yang-rugikan14-bank, diakses 2 oktober 2018.

Rochman, M. N., Andini, R., \& Oemar, A. (2016). Pengaruh Time Presure, Resiko Audit, Materialitas, Prosedur Review dan Kontrol Kualitas, Locus of Control serta Komitmen Profesional terhadap Penghentian Prematur Prosedur (Studi Empiris pada KAP di Palembang). Journal of Accounting, 2(2), 2-10.

Smith, D., \& Hall, M. (2008). An empirical examination of a three- Component model of professional commitment among public accountants. Behavioral Research in Accounting, 20(1), 75-92.

Sugiyono. 2016. Metode Penelitian Kuantitatif, Kualitatif, dan Kombinasi (Mixed Methods). Bandung: Alfabeta.

Siregar, H., Muda, I., \& Fachrudin, K. A. (2018). The Impact of Locus of Control, Etchics Audit, Time Pressure, and Commitment to Deviant Behaviour in Audit at Foreign Affiliated Public Accountants in Medan, Indonesia. Advances in Social Science, Education and Humanities Research, Volume 292, 416-423.

Tamara, W. A. (2017). Pengaruh Komitmen Profesional Affective, Komitmen Profesional Continuance, Komitmen Profesional Normative, Dan Komitmen Organisasi Terhadap Perilaku Disfungsional Auditor. JOM Fekon, Vol.4, 4839-4853.

Wahyudi, I., Lucyanda, J., \& Suhud, L. H. (2011). Praktik penghentian prematur atas prosedur audit. Media Riset Akuntansi, 1(2), 125-140. https://doi.org/10.1111/j.1525-1594.1982.tb01680.x

Weningtyas, S., Setiawan, D., \& Triatmoko, H. (2006). Penghentian prematur atas prosedur audit. Simposium Nasional Akuntansi 9 Padang, 1-33. 